Article

TANVEER, A. ${ }^{1}$

ABBAS, N. ${ }^{1}$

SAFDAR, M.E. ${ }^{2 *}$

IKRAM, R.M. ${ }^{3}$

\section{Alkyl Ether Sulfate Improves Efficacy of Herbicides Against Common Goosefoot AND Field BINDWEED IN WHEAT}

\author{
O Uso do Sulfato de Alquil Éter na Melhora da Eficácia de Herbicidas Contra a \\ Ançarinha-Branca e a Corriola na Cultura do Trigo
}

\begin{abstract}
Tank mixed application of herbicides with adjuvant is required for effective weed management and to reduce herbicide load on agricultural crops. Field studies were conducted to investigate the effect of herbicides at reduced rates with adjuvant on common goosefoot (Chenopodium album) and field bindweed (Convolvulus arvensis) and grain yield of wheat for two consecutive winter seasons. Treatments included post-emergence foliar application of four herbicides viz., fluroxypyr + tribenuron-methyl + clopyralid, mesosulfuron-methyl + iodosulfuron-methyl sodium, bromoxynil + MCPA, iodosulfuron-methyl sodium (pre mixed formulations) at their recommended rates $244.5,14.2,444.6,10 \mathrm{~g}$ a.i. ha ${ }^{-1}$, respectively and $25 \%$ reduced rates with alkyl ether sulfate $\mathrm{Na}$ salt at $400 \mathrm{~mL} \mathrm{ha}^{-1}$ as adjuvant. A weedy check was kept as control. All the herbicide treatments caused a significant reduction in densities (up to $85 \%$ and $89.2 \%$ ) of C. arvensis and C. album, respectively and total dry weight (12.4$56 \%), \mathrm{N}(3.7-50 \%), \mathrm{P}(25-63.6 \%)$ and K (1.4-56.6\%) uptakes from weedy check. Better weed control was achieved with $25 \%$ lower dose of all herbicides along with adjuvant in comparison with that recorded with their full doses without adjuvant. All herbicide treatments increased the grain yield of wheat ranging from 10.4 6-56.1\% over control during both years. Herbicides with adjuvant produced significantly the higher grain yield of wheat than those observed with herbicides alone. Among all herbicide treatments, $75 \%$ doses of bromoxynil + MCPA and iodosulfuron-methyl sodium along with alkyl ether sulfate adjuvant were proved to be the best as they gave significantly the higher (4902.3 and $5159.0 \mathrm{~kg} \mathrm{ha}^{-1}$ and 4566.5 and $4891.0 \mathrm{kgha}^{-1}$ ) grain yields of wheat during years 2013-14 and 2014-15, respectively.
\end{abstract}

Keywords: adjuvant, grain yield, herbicides, wheat

RESUMO - A aplicação de herbicidas em tanque com adjuvante é necessária para o manejo eficaz de plantas daninhas e para a redução da carga de herbicidas em culturas agrícolas. Estudos de campo foram conduzidos para investigar o efeito de herbicidas em doses reduzidas com adjuvante em ansarinha-branca (Chenopodium album) e corriola (Convolvulus arvensis) e no rendimento de grãos de trigo durante duas estações de inverno consecutivas. Os tratamentos incluíram a aplicação foliar em pós-emergência de quatro herbicidas, a saber: fluroxypyr + tribenuronmethyl + clopyralid, mesosulfuron-methyl + iodosulfuron-methyl sodium, bromoxynil + MCPA e iodosulfuron-methyl sodium, com as doses recomendadas (244,5; 14,2; 444,6; e $10 \mathrm{~g}$ i.a. ha $\mathrm{h}^{-1}$, respectivamente), e doses reduzidas em 25\% com sal de sulfato de aquil éter at $400 \mathrm{~mL} \mathrm{ha}^{-1}$ como adjuvante. Um grupo de plantas daninhas sem aplicação de herbicidas foi mantido como controle. Todos os tratamentos com herbicidas causaram redução significativa nas densidades

Planta Daninha 2017; v35:e017164307

1 Department of Agronomy, University of Agriculture, Faisalabad, Pakistan; ${ }^{2}$ Department of Agronomy, University College of Agriculture, University of Sargodha-Pakistan, ${ }^{3}$ Department of Agronomy, MNS University of Agriculture, Multan, Pakistan. 
(até $85 \%$ e 89,2\%) de C. arvensis e C. album, respectivamente, bem como no peso seco total (12.4-56\%), $N(3,7-50 \%), P(25-63,6 \%)$ e K (1,4-56,6\%) das amostras de controle das plantas daninhas. Foi obtido melhor controle das plantas daninhas com uma dose $25 \%$ mais baixa de todos os herbicidas juntamente com o adjuvante, em comparação com o registrado com as doses completas sem adjuvante. Todos os tratamentos com herbicidas aumentaram o rendimento de grãos do trigo, variando em 10,4 $\pm 56,1 \% \mathrm{em}$ relação ao controle, nos anos 2013-14 e 2014-15. Os herbicidas com adjuvante tiveram rendimento de grãos do trigo significativamente maior do que o observado apenas com herbicidas. Entre todos os tratamentos com herbicidas, verificou-se que as doses de bromoxynil + MCPA e iodosulfuron-methyl sodium, juntamente com o adjuvante de éter etílico-sulfato, foram as melhores, uma vez que proporcionaram rendimentos de grãos de trigo significativamente maiores $\left(4902,3\right.$ e 5159,0 $\mathrm{kg} \mathrm{ha}^{-1}$ e 4566,5 e 4891,0 $\mathrm{kg} \mathrm{ha}^{-1}$ ) nos anos 2013-14 e 2014-15, respectivamente.

Palavras-chave: adjuvante, herbicidas, trigo, rendimento de grãos.

\section{INTRODUCTION}

Wheat (Triticum aestivum) is ranked first in world production of cereal crops. It is the staple food of masses and has a leading position in Pakistan's agricultural system: it occupies the largest cultivation area and provides $72 \%$ of the national food basket every year (Malik et al., 2012). The average national grain yield of wheat in Pakistan is $2787 \mathrm{~kg} \mathrm{ha}^{-1}$, which is less than its genetic yield potential of 5928-7904 $\mathrm{kg} \mathrm{ha}^{-1}$ (PARC, 2013). There is a huge gap between actual and potential yield. There are many reasons for this yield gap; however, weed infestation is the most prominent factor. So far, 105 weed species have been identified in various wheat growing areas of Pakistan (Malik et al., 2012). Weed-related decrease in wheat crop yield ranges from 19 to 40\% (Armin and Asghripour, 2011; Abbas et al., 2014).

Chemical weed control is a preferred strategy over other weed control methods because it is quick, easy, economical and effective. Herbicides offer a significant boost up in crop growth by controlling weeds at early stages and through efficient resource utilization by crops, which ultimately leads to higher crop productivity (Santos, 2009). Use of these herbicides seems to be inevitable, as it emerged as an effective way to control weeds and enhance crop yield (Kahramanoglu and Uygur, 2010).

Nevertheless, intensive use of herbicides affects non-targeted organisms, causes soil and environmental pollution and disturbs ecosystems, and may also have an effect on the human health (Duman et al., 2010). Nowadays, there is a dire need to reduce chemical load on agricultural crop production by decreasing chemical rate and spray volume. This may be possible by optimizing the efficiency of herbicides at a reduced rate by adding an adjuvant (Devendra et al., 2004). An adjuvant reduces the energy and time required to absorb active ingredients across the external leaf membrane barriers or cuticle, enhances the range of herbicides selectivity and coverage of spray droplets on plant tissues rather than beading up and rolling off (Tagour et al., 2011).

Mixture of two or more than two herbicides is a common practice for efficient weed control because of their different modes of action and management of herbicide resistance. Fluroxypyr, tribenuron-methyl, clopyralid, iodosulfuron methyl, mesosulfuron-methyl, iodosulfuron-methyl sodium, bromoxynil and MCPA are selective herbicides which are used for the control of broadleaf weeds in wheat. Fluroxypyr and clopyralid belong to the pyridine-carboxylic acid family while MCPA belongs to the phenoxy-carboxylic acid group. All these herbicides control weeds by disrupting cell growth and cell division in newly-forming leaves, leading to malformed growth and tumors. Tribenuron-methyl, mesosulfuron and iodosulfuron belong to the sulfonylurea group and block the normal functioning of the acetolactate synthase enzyme, which is essential for protein synthesis. Bromoxynil belongs to the nitrile family and inhibits photosynthesis at PS-II. Different types of adjuvants (surfactants, oils, emulsifiers and fertilizer salts such as ammonium sulfate) have been found to enhance the activity of various foliar-applied herbicides against weeds (Kirkwood, 1993). Bryan et al. (2003) showed a differential increase in glyphosate absorption by two weed species (common lambsquarters and velvetleaf) by addition of ammonium sulfate as an adjuvant. Absorption of glyphosate was significantly increased by velvetleaf while no improvement 
was noted with lambsquarters. Varshney and Singh (1990) found 67\% reduction in weed biomass by adding the isoctyl phenyl polyethoxy ethanol adjuvant in 33\% reduced rates of terbutryn, isoproturon, methabenzthiazuron and metoxuron compared with the herbicide alone. Among different adjuvants used, Knezevic et al. (2009) found the highest improvement in efficacy of saflufenacil against field bindweed in wheat by addition of methylated seed oil. There is little or no information available about the effect of the alkyl ether sulfate adjuvant when used with herbicides in wheat crop for controlling common goosefoot and field bindweed. Therefore, the present study was undertaken with a view to optimizing the rate of a range of herbicides at a reduced rate with alkyl ether sulfate as an adjuvant on common goosefoot and field bindweed in wheat.

\section{MATERIALS AND METHODS}

A two-year field trial was conducted during the winter season (2013-14 and 2014-15) at Students Farm, Department of Agronomy, University of Agriculture, Faisalabad, Pakistan. The experimental site was located at $31.25^{\circ} \mathrm{N}$ latitude, $73.09^{\circ} \mathrm{E}$ longitude and $184.4 \mathrm{~m}$ above sea level. The experiment was laid out in randomized complete block design with four replications. Each replication consisted of nine treatments, where each with plot was $1.5 \mathrm{~m}$ wide and $6 \mathrm{~m}$ long. Row to row distance was $25 \mathrm{~cm}$. A wheat cultivar (Punjab, 2009) was sown as a test crop on $12^{\text {th }}$ November in 2013 and $14^{\text {th }}$ November in 2014 . The recommended seed rate of $100 \mathrm{~kg}$ ha ${ }^{1}$ was used. Fertilizer was applied at the rate of $125 \mathrm{~kg} \mathrm{~N}, 85 \mathrm{~kg} \mathrm{P}_{2} \mathrm{O}_{5}$ and $75 \mathrm{~kg} \mathrm{~K}_{2} \mathrm{O} \mathrm{ha}^{-1}$. Half of the $\mathrm{N}$ and the whole $\mathrm{P}_{2} \mathrm{O}_{5}$ and $\mathrm{K}_{2} \mathrm{O}$ were applied at the time of sowing while half rate of $\mathrm{N}$ was applied at the time of first irrigation by the broadcast method. A total of three irrigations were applied to the wheat crop. The first irrigation was given at crown root initiation stage within 22 days after sowing; the second irrigation was applied at the tillering stage i.e. 40-45 days after sowing. The third irrigation was scheduled at the milking stage within 90-95 days after sowing. All the herbicide treatments were applied at post-emergence, as shown in Table 1.

Herbicide application dates were January 24 and 26 in 2014 and 2015, respectively, after the 1st irrigation in optimum moisture condition at almost 2-3 leaf stage of weeds. Herbicides were sprayed with a backpack knapsack sprayer fitted with a Tee Jet 8002 flat-fan nozzle at $234 \mathrm{k} \mathrm{Pa}$ calibrated to deliver $250 \mathrm{~L} \mathrm{ha}^{-1}$ at the speed of $3.2 \mathrm{~km} \mathrm{~h}^{-1}$ on the respective plot of $6.0 \mathrm{~m} \times 1.5 \mathrm{~m}$. The spray solution was prepared in a bottle containing tap water. The adjuvant (Buyer crop science) was tank-mixed with herbicides before application. Data were recorded on individual broadleaf weed density, dry weight, nutrient uptake, yield and yield components of wheat. Oven-dried samples of weeds taken from a $1.0 \times 1.0 \mathrm{~m}$ area from two different places in each plot of each replication and were then ground. Nitrogen, P and K were determined by the

Table 1 - Treatments used in the experiment

\begin{tabular}{|l|c|c|}
\hline \multicolumn{1}{|c|}{ Herbicide Treatments } & Rate $\left(\mathrm{g}\right.$ a.i. ha $\left.{ }^{-1}\right)$ & Adjuvant \\
\hline Weedy check & - & - \\
\hline $\begin{array}{l}\text { Fluroxypyr + tribenuron-methyl + } \\
\text { clopyralid }\end{array}$ & 244.5 & - \\
\hline $\begin{array}{l}\text { Mesosulfuron-methyl + iodosulfuron- } \\
\text { methyl sodium }\end{array}$ & 14.2 & - \\
\hline Bromoxynil + MCPA & 444.6 & - \\
\hline Iodosulfuron-methyl sodium & 10 & Alkyl ether sulfate Na salt @ $400 \mathrm{~mL} \mathrm{ha}^{-1}$ \\
\hline $\begin{array}{l}\text { Fluroxypyr + tribenuron-methyl+ } \\
\text { clopyralid }\end{array}$ & $183.3^{(1)}$ & Alkyl ether sulfate Na salt @ $400 \mathrm{~mL} \mathrm{ha}^{-1}$ \\
\hline $\begin{array}{l}\text { Mesosulfuron-methyl + iodosulfuron- } \\
\text { methyl sodium }\end{array}$ & $10.6^{(1)}$ & Alkyl ether sulfate Na salt @ $400 \mathrm{~mL} \mathrm{ha}^{-1}$ \\
\hline Bromoxynil + MCPA & $333.4^{(1)}$ & Alkyl ether sulfate Na salt @ $400 \mathrm{~mL} \mathrm{ha}^{-1}$ \\
\hline Iodosulfuron-methyl sodium & $7.5^{\dagger}$ & \\
\hline
\end{tabular}

(1) Reduced rate ( $75 \%$ of the recommended rate). 
Wolf (1982) method. The data collected were analyzed statistically by Fisher's analysis of variance technique. Individual comparison of treatment means were made by using Tukey's honestly significant difference test at 0.05 probability level (Steel et al., 1997). Preplanned orthogonal contrasts were used to compare herbicides with and without adjuvant.

\section{RESULTS AND DISCUSSION}

\section{Growth characteristics of weeds}

\section{Weed density $\left(\mathrm{m}^{-2}\right)$}

Broadleaf weeds present in the field were common goosefoot (Chenopodium album) and field bindweed (Convolvulus arvensis). The data on individual weed density $\left(\mathrm{m}^{-2}\right)$ of C. arvensis and C. album are shown in Table 2, which indicated that all herbicides suppressed C. arvensis and C. album density in wheat 3 weeks after spray application (WAS), ranging from 62.5 to 85 and 62.6 to 83.5 percent compared with the weedy check during years 2013-14 and 2014-15, respectively. Contrast comparison showed that. in both years, herbicides at $75 \%$ of their recommended rate along with alkyl ether sulfate sodium salt as an adjuvant resulted in significantly lower density of this weed (7.25 and 7.12 plants $\mathrm{m}^{-2}$ in year 2013-14 and 2014-15, respectively) than noted with treatments receiving full rates of herbicides without an adjuvant.

The individual comparison of treatment means indicated that bromoxynil + MCPA showed best results with the adjuvant as $75 \%$ of the recommended rate in combination with alkyl ether sulfate sodium salt caused maximum decline (83.5-85\%) in C. arvensis density. However, the

Table 2 - Effect of herbicides with and without an adjuvant on individual weed density $\left(\mathrm{m}^{-2}\right)$ at 3 weeks after spray ( 90 days after crop emergence)

\begin{tabular}{|c|c|c|c|c|c|c|}
\hline \multirow{2}{*}{ Herbicide } & \multirow{2}{*}{$\begin{array}{c}\text { Rate } \\
\left(\mathrm{g} \mathrm{a} \text { a.i. } \mathrm{ha}^{-1}\right)\end{array}$} & \multirow{2}{*}{ Adjuvant } & \multicolumn{2}{|c|}{ C. album } & \multicolumn{2}{|c|}{ C. arvensis } \\
\hline & & & $2014-15$ & 2013-14 & $2014-15$ & 2013-14 \\
\hline Un-weeded control & - & - & $34.75 \mathrm{a}$ & $36.75 \mathrm{a}$ & $34.75 \mathrm{a}$ & $40.00 \mathrm{a}$ \\
\hline $\begin{array}{l}\text { Fluroxypyr + tribenuron- } \\
\text { methyl + clopyralid }\end{array}$ & 244.5 & - & $\begin{array}{l}14.25 \mathrm{~b} \\
(59.0)\end{array}$ & $\begin{array}{l}16.00 \mathrm{~b} \\
(56.5)\end{array}$ & $\begin{array}{l}13.0 \mathrm{~b} \\
(62.6)\end{array}$ & $\begin{array}{l}15.00 \mathrm{~b} \\
(62.5)\end{array}$ \\
\hline $\begin{array}{l}\text { Mesosulfuron-methyl }+ \\
\text { iodosulfuron-methyl sodium }\end{array}$ & 14.2 & - & $\begin{array}{l}12.75 \mathrm{bc} \\
(63.3)\end{array}$ & $\begin{array}{l}15.00 \mathrm{~b} \\
(59.2)\end{array}$ & $\begin{array}{l}13.0 \mathrm{~b} \\
(62.6)\end{array}$ & $\begin{array}{l}13.25 \mathrm{bc} \\
(66.9)\end{array}$ \\
\hline Bromoxynil + MCPA & 444.6 & - & $\begin{array}{l}12.00 \mathrm{bc} \\
(65.5)\end{array}$ & $\begin{array}{l}12.25 \mathrm{~b} \\
(66.7)\end{array}$ & $\begin{array}{l}12.0 \mathrm{~b} \\
(65.5)\end{array}$ & $\begin{array}{l}13.25 \mathrm{bc} \\
(66.9)\end{array}$ \\
\hline Iodosulfuron-methyl sodium & 10 & - & $\begin{array}{l}11.50 \mathrm{bc} \\
(66.9)\end{array}$ & $\begin{array}{l}12.50 \mathrm{~b} \\
(66.0)\end{array}$ & $\begin{array}{l}10.25 \mathrm{bc} \\
(70.5)\end{array}$ & $\begin{array}{l}10.0 \mathrm{bcd} \\
(75.0)\end{array}$ \\
\hline $\begin{array}{l}\text { Fluroxypyr + tribenuron- } \\
\text { methyl + clopyralid }\end{array}$ & $183.3^{(1)}$ & $\begin{array}{l}\text { Alkyl ether sulfate } \mathrm{Na} \\
\text { salt @ } 400 \mathrm{~mL} \mathrm{ha}^{-1}\end{array}$ & $\begin{array}{l}10.00 \mathrm{bc} \\
(71.2)\end{array}$ & $\begin{array}{l}11.25 \mathrm{~b} \\
(69.4)\end{array}$ & $\begin{array}{l}8.25 \mathrm{bc} \\
(76.3)\end{array}$ & $\begin{array}{l}8.25 \mathrm{bcd} \\
(79.4)\end{array}$ \\
\hline $\begin{array}{l}\text { Mesosulfuron-methyl }+ \\
\text { iodosulfuron-methyl sodium }\end{array}$ & $10.6^{(1)}$ & $\begin{array}{l}\text { Alkyl ether sulfate } \mathrm{Na} \\
\text { salt @ } 400 \mathrm{~mL} \mathrm{ha}^{-1}\end{array}$ & $\begin{array}{l}8.25 \mathrm{bc} \\
(76.3)\end{array}$ & $\begin{array}{l}7.75 \mathrm{~b} \\
(78.9)\end{array}$ & $\begin{array}{l}7.25 \mathrm{bc} \\
(79.1)\end{array}$ & $\begin{array}{l}7.50 \mathrm{~cd} \\
(81.3)\end{array}$ \\
\hline Bromoxynil + MCPA & $333.4^{(1)}$ & $\begin{array}{l}\text { Alkyl ether sulfate } \mathrm{Na} \\
\text { salt @ } 400 \mathrm{~mL} \mathrm{ha}^{-1}\end{array}$ & $\begin{array}{l}5.50 \mathrm{bc} \\
(84.2)\end{array}$ & $\begin{array}{l}4.75 \mathrm{~b} \\
(87.1)\end{array}$ & $\begin{array}{l}5.75 \mathrm{c} \\
(83.5)\end{array}$ & $\begin{array}{l}6.00 \mathrm{~d} \\
(85.0)\end{array}$ \\
\hline Iodosulfuron-methyl sodium & $7.5^{(1)}$ & $\begin{array}{l}\text { Alkyl ether sulfate } \mathrm{Na} \\
\text { salt @ } 400 \mathrm{~mL} \mathrm{ha}^{-1}\end{array}$ & $\begin{array}{l}3.75 \mathrm{c} \\
(89.2)\end{array}$ & $\begin{array}{l}5.75 \mathrm{~b} \\
(84.4)\end{array}$ & $\begin{array}{l}7.25 \mathrm{bc} \\
(79.1)\end{array}$ & $\begin{array}{l}7.25 \mathrm{~cd} \\
(81.9)\end{array}$ \\
\hline HSD & & & 9.83 & 11.88 & 5.79 & 6.98 \\
\hline \multicolumn{7}{|c|}{ Contrasts } \\
\hline Weedy check vs all & & & 34.75 vs $10.21 * *$ & 36.75 vs $10.65^{* *}$ & 34.75 vs $9.59^{* *}$ & 40 vs $10.06^{* *}$ \\
\hline $\begin{array}{l}\text { Herbicides without an adjuvant } \\
\text { vs herbicides with an adjuvant }\end{array}$ & & & 12.62 vs $7.81^{* *}$ & 13.93 vs $7.37 *$ & 12.06 vs $7.12 * *$ & 12.87 vs $7.25 * *$ \\
\hline
\end{tabular}

(1) Reduced rate ( $75 \%$ of the recommended rate); Means sharing the same letter did not differ significantly at $p \leq 0.05$, Values in parenthesis are percent decreases from the unweeded control. 
other three herbicides viz., iodosulfuron-methyl sodium, mesosulfuron-methyl + iodosulfuronmethyl sodium and fluroxypyr + tribenuron-methyl + clopyralid could be ranked in the second, third and fourth positions, respectively, in this regard. Our findings are parallel to those of Javaid et al. (2012), who recorded $100 \%$ control of Emex spinose with bromoxynil+ MCPA applied at a reduced rate with alkyl ether sulfate sodium salt.

Data on density of $C$. album during the two years of study are shown in Table 2 and indicate that all herbicide treatments significantly reduced the population of this weed in wheat ranging from 56.5 to $87.1 \%$ and 59 to $89.2 \%$ during years $2013-14$ and 2014-15, respectively. Contrast analysis indicated that $C$. album weed density registered with treatments spayed with herbicides whose rates were $25 \%$ lower, along with alkyl ether sulfate as an adjuvant, was significantly lower than density from full herbicide rates without an adjuvant (Table 2). When herbicides were applied without an adjuvant in C. album, density was significantly higher than when herbicides were sprayed with an adjuvant. Thus, it appeared that herbicide application with an adjuvant is more effective than herbicide application alone in controlling C. arvensis and C. album in wheat.

This outcome could be due to a decrease in the surface tension of the herbicide solution that produces small droplets and, as there is a low level of energy in small droplets, retention of a herbicide by the leaf surface improves (Penner, 2000). Enhanced activity of tribenuron- methyl by alkyl ether sulfate sodium salt on C. album was reported by Pannacci et al. (2010). Furthermore, these results were also in accordance with those of Han and Tao (2011), who mentioned that adjuvant addition enhanced fomesafen efficacy, thereby effectively controlling weeds. Differences in the activity of herbicides that were observed among the study weeds may be due to differences in the retention and/or uptake of the herbicides, probably as a result of differences in branching habit, cuticle and leaf area ratio (Hess and Foy, 2000; Bellinder et al., 2003).

\section{Dry weight of broadleaf weeds $\left(\mathrm{g} \mathrm{m}^{-2}\right)$}

Data in Table 3 showed that all herbicide treatments considerably reduced total dry weight of broadleaf weeds ranging from 12.4 to $56 \%$ in 2014-15. Contrast comparison showed that in 2013-14, herbicides without an adjuvant combination gave $54.45 \mathrm{~g} \mathrm{~m}^{-2}$ total dry weight of weeds, which was significantly higher than the value recorded with treatments where herbicides were used along with an adjuvant. There was a similar trend during 2014-15. The lowest dry weight of broadleaf weeds $\left(35.70\right.$ and $\left.28.95 \mathrm{~g} \mathrm{~m}^{-2}\right)$ was found in the plots where bromoxynil + MCPA at $333.4 \mathrm{~g}$ a.i. ha $\mathrm{ha}^{-1}$ alkyl ether sulfate $\mathrm{Na}$ salt at $400 \mathrm{~mL} \mathrm{ha} \mathrm{m}^{-1}$ were sprayed during years 2013-14 and 2014-15, respectively. However, this treatment did not differ significantly from other herbicides sprayed with an adjuvant except for fluroxypyr + tribenuron-methyl + clopyralid with respect to efficacy against broadleaf weeds. Fluroxypyr + tribenuron-methyl + clopyralid at $244.5 \mathrm{~g}$ a.i. $\mathrm{ha}^{-1}$ remained at the lowest position in this regard, with the highest total dry weight (58.47 and $57.70 \mathrm{~g} \mathrm{~m}^{-2}$ ) in years 2013-14 and 2014-15, respectively.

The highest total dry weight of weeds in the weedy check was due to a higher number of weeds and their vigorous growth. Chemical weed control practices either caused death or suppression of weeds, ultimately reducing their biomass and weight. Variation in total dry weight of weeds was due to varying effects of herbicides on their growth. These results are in line with those of Devendra et al. (2004), who concluded that addition of surfactants laffmul DA and ethoxylated castor oil (EO 40) with 67.7 and $76.4 \mathrm{mN} / \mathrm{m}$ surface tension, respectively, to different herbicides spray solutions, altered herbicide efficacy through biomass reduction of Cyperus rotundus and Oxalis latifolia. Moreover, these results are also similar to those of Donald (2010), who reported that adding a surfactant $(0.2 \% \mathrm{v} / \mathrm{v}$ Tween 80$)$ to chlorsulfuron helped to stop further root growth of weeds, thus ultimately reducing weed dry weight. Singh et al. (2013b) stated that post-emergence herbicides metsulfuron and 2.4-D at $6 \mathrm{~g}$ and $500 \mathrm{~g}$ a.i. ha ${ }^{-1}$ at 30-35 days after sowing in wheat field reduced weed dry weight up to $67.4 \%$.

\section{NPK uptake by weeds (kg ha-1)}

The data given in Table 3 showed that the application of herbicides reduced nutrient uptake by weeds by reducing the weed population. Phosphorus uptake by weeds was significantly 
TANVEER, A. et al. Alkyl ether sulfate improves efficacy of herbicides against common goosefoot and field bindweed in wheat

Table 3 - Effect of herbicides with and without an adjuvant on total dry weight $\left(\mathrm{g} \mathrm{m}^{-2}\right)$ of broadleaf weeds and NPK uptake (kg ha-1)

\begin{tabular}{|c|c|c|c|c|c|c|c|c|c|c|}
\hline \multirow[t]{2}{*}{ Herbicide } & \multirow[t]{2}{*}{$\begin{array}{c}\text { Rate } \\
\left(\mathrm{g} \mathrm{a} \text { a.i. } \mathrm{a}^{-1}\right)\end{array}$} & \multirow[t]{2}{*}{ Adjuvant } & \multicolumn{2}{|c|}{$\begin{array}{l}\text { Total dry weight of } \\
\text { broadleaf weeds } \\
\left(\mathrm{g} \mathrm{m}^{-2}\right)\end{array}$} & \multicolumn{2}{|c|}{$\begin{array}{l}\text { N uptake by weeds } \\
\left(\mathrm{kg} \mathrm{ha}^{-1}\right)\end{array}$} & \multicolumn{2}{|c|}{$\begin{array}{l}\text { P uptake by weeds } \\
\left(\mathrm{kg} \mathrm{ha}^{-1}\right)\end{array}$} & \multicolumn{2}{|c|}{$\begin{array}{l}\text { K uptake by weeds } \\
\left(\mathrm{kg} \mathrm{ha}^{-1}\right)\end{array}$} \\
\hline & & & $2014-15$ & $2013-14$ & $2014-15$ & $2013-14$ & $2014-15$ & $2013-14$ & $2014-15$ & $2013-14$ \\
\hline Unweeded control & - & - & $65.87 \mathrm{a}$ & $71.32 \mathrm{a}$ & $10.06 \mathrm{a}$ & $10.32 \mathrm{a}$ & $9.66 \mathrm{a}$ & $9.44 \mathrm{a}$ & $8.73 \mathrm{a}$ & $9.73 \mathrm{a}$ \\
\hline $\begin{array}{l}\text { Fluroxypyr + tribenuron- } \\
\text { methyl + clopyralid }\end{array}$ & 244.5 & - & $\begin{array}{l}57.70 \mathrm{ab} \\
(12.4) \\
\end{array}$ & $\begin{array}{l}58.47 \mathrm{~b} \\
(18.0)\end{array}$ & $\begin{array}{l}8.36 \text { abcd } \\
(16.9) \\
\end{array}$ & $\begin{array}{l}9.35 \mathrm{ab} \\
(9.4) \\
\end{array}$ & $\begin{array}{l}4.25 \text { ef } \\
(56.0)\end{array}$ & $\begin{array}{l}4.55 \mathrm{~d} \\
(51.8) \\
\end{array}$ & $\begin{array}{l}8.61 \mathrm{a} \\
(1.4) \\
\end{array}$ & $\begin{array}{l}8.72 \mathrm{ab} \\
(10.4) \\
\end{array}$ \\
\hline $\begin{array}{l}\text { Mesosulfuron-methyl }+ \\
\text { iodosulfuron-methyl sodium }\end{array}$ & 14.2 & - & $\begin{array}{l}54.42 \mathrm{bc} \\
(17.4)\end{array}$ & $\begin{array}{l}56.47 \mathrm{~b} \\
(20.8)\end{array}$ & $\begin{array}{l}9.69 \mathrm{ab} \\
(3.7)\end{array}$ & $\begin{array}{l}9.64 \mathrm{ab} \\
(6.6)\end{array}$ & $\begin{array}{l}5.49 \text { bcde } \\
(43.2)\end{array}$ & $\begin{array}{l}5.33 \mathrm{~cd} \\
(43.5)\end{array}$ & $\begin{array}{l}8.13 \mathrm{ab} \\
(6.9)\end{array}$ & $\begin{array}{l}9.12 \mathrm{ab} \\
(6.3)\end{array}$ \\
\hline Bromoxynil + MCPA & 444.6 & - & $\begin{array}{l}52.75 \mathrm{bc} \\
(19.9)\end{array}$ & $\begin{array}{l}53.75 \mathrm{bc} \\
(24.6)\end{array}$ & $\begin{array}{l}8.92 \mathrm{abc} \\
(11.3)\end{array}$ & $\begin{array}{l}9.14 \mathrm{ab} \\
(11.4)\end{array}$ & $\begin{array}{l}7.13 \mathrm{~b} \\
(26.2)\end{array}$ & $\begin{array}{l}6.86 \mathrm{~b} \\
(27.3)\end{array}$ & $\begin{array}{l}8.47 \mathrm{a} \\
(3.0)\end{array}$ & $\begin{array}{l}9.45 \mathrm{ab} \\
(2.9)\end{array}$ \\
\hline Iodosulfuron-methyl sodium & 10 & - & $\begin{array}{l}46.15 \mathrm{~cd} \\
(29.9)\end{array}$ & $\begin{array}{l}49.1 \mathrm{bcd} \\
(31.1)\end{array}$ & $\begin{array}{l}8.01 \mathrm{bcd} \\
(20.4)\end{array}$ & $\begin{array}{l}8.19 \mathrm{bc} \\
(20.6)\end{array}$ & $\begin{array}{l}6.93 \mathrm{bc} \\
(28.3)\end{array}$ & $\begin{array}{l}7.08 \mathrm{~b} \\
(25.0)\end{array}$ & $\begin{array}{l}6.70 \mathrm{bc} \\
(23.3)\end{array}$ & $\begin{array}{l}7.86 \mathrm{bc} \\
(19.2)\end{array}$ \\
\hline $\begin{array}{l}\text { Fluroxypyr + tribenuron- } \\
\text { methyl +clopyralid }\end{array}$ & $183.3^{(1)}$ & & $\begin{array}{l}42.40 \mathrm{de} \\
(35.6)\end{array}$ & $\begin{array}{l}46.30 \mathrm{~cd} \\
(35.1)\end{array}$ & $\begin{array}{l}7.14 \text { cde } \\
(29.0)\end{array}$ & $\begin{array}{l}8.15 \mathrm{bc} \\
(21.0)\end{array}$ & $\begin{array}{l}6.22 \mathrm{bcd} \\
(35.6)\end{array}$ & $\begin{array}{l}6.46 \mathrm{bc} \\
(31.6)\end{array}$ & $\begin{array}{l}6.35 \mathrm{c} \\
(27.3)\end{array}$ & $\begin{array}{l}6.46 \mathrm{~cd} \\
(33.6)\end{array}$ \\
\hline $\begin{array}{l}\text { Mesosulfuron-methyl }+ \\
\text { iodosulfuron-methyl sodium }\end{array}$ & $10.6^{(1)}$ & $\begin{array}{l}\text { Alkyl ether sulfate Na } \\
\text { salt @ } 400 \mathrm{~mL} \mathrm{ha}^{-1}\end{array}$ & $\begin{array}{l}38.95 \mathrm{def} \\
(40.9)\end{array}$ & $\begin{array}{l}42.10 \mathrm{de} \\
(41.0)\end{array}$ & $\begin{array}{l}6.83 \mathrm{def} \\
(32.1) \\
\end{array}$ & $\begin{array}{l}7.17 \mathrm{c} \\
(30.5) \\
\end{array}$ & $\begin{array}{l}5.21 \mathrm{de} \\
(46.1) \\
\end{array}$ & $\begin{array}{l}5.34 \mathrm{~cd} \\
(43.4) \\
\end{array}$ & $\begin{array}{l}5.26 \mathrm{~cd} \\
(39.7) \\
\end{array}$ & $\begin{array}{c}5.94 \mathrm{~d} \\
(39.0) \\
\end{array}$ \\
\hline Bromoxynil + MCPA & $333.4^{(1)}$ & $\begin{array}{l}\text { Alkyl ether sulfate } \mathrm{Na} \\
\text { salt @ } 400 \mathrm{~mL} \mathrm{ha}^{-1}\end{array}$ & $\begin{array}{l}28.95 \mathrm{f} \\
(56.0)\end{array}$ & $\begin{array}{l}35.70 \mathrm{e} \\
(49.9)\end{array}$ & $\begin{array}{l}5.04 \mathrm{f} \\
(49.9)\end{array}$ & $\begin{array}{l}6.38 \mathrm{c} \\
(38.2)\end{array}$ & $\begin{array}{l}3.52 \mathrm{f} \\
(63.6)\end{array}$ & $\begin{array}{l}4.22 \mathrm{~d} \\
(55.3)\end{array}$ & $\begin{array}{l}3.79 \mathrm{~d} \\
(56.6)\end{array}$ & $\begin{array}{l}5.65 \mathrm{~d} \\
(41.9) \\
\end{array}$ \\
\hline Iodosulfuron-methyl sodium & $7.5^{(1)}$ & $\begin{array}{l}\text { Alkyl ether sulfate } \mathrm{Na} \\
\text { salt @ } 400 \mathrm{~mL} \mathrm{ha}^{-1}\end{array}$ & $\begin{array}{l}34.65 \text { ef } \\
(47.4)\end{array}$ & $\begin{array}{l}39.97 \mathrm{de} \\
(44.0)\end{array}$ & $\begin{array}{l}5.89 \text { ef } \\
(41.5)\end{array}$ & $\begin{array}{l}6.79 \mathrm{c} \\
(34.2)\end{array}$ & $\begin{array}{l}5.31 \mathrm{cde} \\
(45.0)\end{array}$ & $\begin{array}{l}5.90 \mathrm{bc} \\
(37.5)\end{array}$ & $\begin{array}{l}5.00 \mathrm{~cd} \\
(42.7)\end{array}$ & $\begin{array}{l}6.92 \mathrm{~cd} \\
(28.9)\end{array}$ \\
\hline HSD & & $\begin{array}{l}\text { Alkyl ether sulfate Na } \\
\text { salt @ } 400 \mathrm{~mL} \mathrm{ha}^{-1}\end{array}$ & 10.14 & 9.55 & 2.0 & 1.92 & 1.67 & 1.22 & 1.73 & 1.69 \\
\hline \multicolumn{11}{|c|}{ Contrasts } \\
\hline Weedy check vs all & & & $\begin{array}{l}65.87 \mathrm{vs} \\
44.49^{* *}\end{array}$ & $\begin{array}{l}71.32 \mathrm{vs} \\
47.73^{* *}\end{array}$ & $\begin{array}{l}8.36 \mathrm{vS} \\
7.71^{\mathrm{NS}}\end{array}$ & $\begin{array}{c}10.32 \mathrm{vs} \\
8.1^{* *}\end{array}$ & $\begin{array}{l}9.66 \mathrm{vS} \\
5.50^{\mathrm{NS}}\end{array}$ & $\begin{array}{l}9.44 \mathrm{vs} \\
5.71^{\mathrm{NS}}\end{array}$ & $\begin{array}{l}8.73 \text { vs } \\
6.61 * *\end{array}$ & $\begin{array}{l}9.73 \text { vs } \\
7.52 * *\end{array}$ \\
\hline $\begin{array}{l}\text { Herbicides without an } \\
\text { adjuvant vs herbicides with } \\
\text { an adjuvant }\end{array}$ & & & $\begin{array}{l}52.75 \text { vs } \\
36.23^{* *}\end{array}$ & $\begin{array}{l}54.45 \mathrm{vs} \\
41.01^{* *}\end{array}$ & $\begin{array}{l}9.19 \mathrm{vs} \\
6.23^{* *}\end{array}$ & $\begin{array}{l}9.08 \text { vs } \\
7.12 * *\end{array}$ & $\begin{array}{l}5.95 \mathrm{vs} \\
5.06^{* *}\end{array}$ & $\begin{array}{l}5.95 \mathrm{vs} \\
5.48^{* *}\end{array}$ & $\begin{array}{l}8.13 \text { vs } \\
5.1^{* *}\end{array}$ & $\begin{array}{l}8.79 \mathrm{vs} \\
6.25^{* *}\end{array}$ \\
\hline
\end{tabular}

(1) Reduced rate $(75 \%$ of the recommended rate); Means sharing the same letter did not differ significantly at $p \leq 0.05$. Values in parenthesis are percent decreases from the unweeded control.

decreased by all herbicide treatments compared with the control in both years of study. The reduction in $\mathrm{P}$ uptake by weeds ranged from 25 to $63.6 \%$ compared with the weedy check. However, in the case of $\mathrm{N}$ and $\mathrm{K}$ uptake by weeds, all the herbicides alone, except for iodosulfuron-methyl sodium, could not cause a significant reduction in the uptake of these nutrients as compared with the weedy check. Nevertheless, all the herbicides at $75 \%$ of the recommended rates in mixture with the alkyethersulfate adjuvant significantly lowered the uptake of N (21.0 to 49.9\%) and $\mathrm{K}(27.3$ to $56.6 \%)$ by weeds in both study years.

Contrast comparison (Table 3) showed a significant difference between herbicides alone and herbicides in mixture with an adjuvant regarding NPK uptake by broadleaf weeds during both years of study. The lowest $\mathrm{N}$ uptake $\left(6.38\right.$ and $\left.5.04 \mathrm{~kg} \mathrm{ha}^{-1}\right)$ was recorded with bromoxynil + MCPA at $333.4 \mathrm{~g}$ a.i. ha ${ }^{-1}+$ alkyl ether sulfate $\mathrm{Na}$ salt at $400 \mathrm{~mL} \mathrm{ha}^{-1}$ and iodosulfuron-methyl sodium at $7.5 \mathrm{~g}$ a.i. ha- ${ }^{-1}$ alkyl ether sulfate $\mathrm{Na}$ salt at $400 \mathrm{~mL} \mathrm{ha}^{-1}\left(6.79\right.$ and $\left.5.89 \mathrm{~kg} \mathrm{ha}^{-1}\right)$. During 2014-15, the highest $\mathrm{N}$ uptake $\left(9.69 \mathrm{~kg} \mathrm{ha}^{-1}\right)$ was recorded with mesosulfuron-methyl + iodosulfuron-methyl sodium at $14.2 \mathrm{~g}$ a.i. ha ${ }^{-1}$. Data on P uptake are shown in Table 3, which revealed that herbicide treatments lowered the $\mathrm{P}$ uptake from soil by weeds because of reduced weed density. Contrast of herbicides when used alone caused (5.95 $\mathrm{kg} \mathrm{ha}^{-1}$ ) P uptake from soil, which was significantly higher than when an adjuvant was used $\left(5.48 \mathrm{~kg} \mathrm{ha}^{-1}\right)$. There was a similar trend during 2014-15. The highest $\mathrm{P}$ uptake $\left(7.08,7.13 \mathrm{~kg} \mathrm{ha}^{-1}\right)$ was recorded with iodosulfuron-methyl sodium at $10.0 \mathrm{~g}$ a. $\mathrm{ha}^{-1}$ and bromoxinil + MCPA at $444.6 \mathrm{~g}$ a.i. ha-1 during 2013-14 and 2014-15, respectively. The lowest P uptake $\left(4.22,3.52 \mathrm{~kg} \mathrm{ha}^{-1}\right)$ was found with bromoxynil + MCPA at $333.4 \mathrm{~g}$ a.i. ha ${ }^{-1}+$ alkyl ether sulfate $\mathrm{Na}$ salt at $400 \mathrm{ml} \mathrm{ha}^{-1}$ during both years.

The data given in Table 3 revealed that herbicide application decreased $\mathrm{K}$ uptake by weeds as a result of a lower weed population. Herbicides when applied alone caused $\left(8.79 \mathrm{~kg} \mathrm{ha}{ }^{1}\right) \mathrm{K}$ uptake compared to when herbicides were used along with an adjuvant $\left(6.25 \mathrm{~kg} \mathrm{ha}^{-1}\right)$ as shown by contrast comparison. Similar trend was noted during 2014-15. In 2013-14, the highest K 
uptake $\left(9.45 \mathrm{~kg} \mathrm{ha}^{-1}\right)$ was observed with bromoxynil + MCPA at $444.6 \mathrm{~g}$ a.i. ha ${ }^{-1}$. The lowest $\mathrm{K}$ uptake $\left(5.65 \mathrm{~kg} \mathrm{ha}^{-1}\right)$ was recorded with bromoxynil + MCPA at $333.4 \mathrm{~g}$ a.i. ha $\mathrm{h}^{-1}+$ alkyl ether sulfate Na salt at $400 \mathrm{~mL} \mathrm{ha}^{-1}$. During $2014-15$, the highest potassium uptake $\left(8.61 \mathrm{~kg} \mathrm{ha}^{-1}\right)$ was recorded with fluroxypyr + tribenuron-methyl + clopyralid at $244.5 \mathrm{~g}$ a.i. ha ${ }^{-1}$. The lowest $\mathrm{K}$ uptake (3.79 $\mathrm{kg} \mathrm{ha}^{-1}$ ) was recorded in plots treated with bromoxynil + MCPA at $333.4 \mathrm{~g}$ a.i. ha-1 + alkyl ether sulfate $\mathrm{Na}$ salt at $400 \mathrm{~mL} \mathrm{ha}^{-1}$. It was followed by that of iodosulfuron-methyl sodium at $7.5 \mathrm{~g}$ a.i. ha ${ }^{-1}+$ alkyl ether sulfate $\mathrm{Na}$ salt at $400 \mathrm{~mL} \mathrm{ha}^{-1}\left(5.00 \mathrm{~kg} \mathrm{ha}^{-1}\right)$. These results were in line with those of Pisal and Sagarka (2013), who mentioned that weed management practices minimized nutrients because of weeds.

\section{Yield and yield components of wheat}

\section{Yield components of wheat}

Table 4 shows data regarding yield related traits of wheat as influenced by different herbicide treatments. An overlook of the contrast comparison showed that all herbicide treatments brought a significant improvement in all yield components compared to the weedy check. Furthermore, herbicides with an adjuvant remained significantly better than without an adjuvant regarding spike bearing tillers, and grains per spike of wheat during both years of study. However, 1000 grain weight of wheat in herbicide treatments with an adjuvant was significantly higher in herbicide treatments without an adjuvant in year 2014-15 only.

An individual comparison of treatment means indicated that among herbicide treatments, $75 \%$ rate of bromoxynil + MCPA along with tank mixed application of alkyl ether sulfate resulted in the highest number of spike bearing tillers (382.5 and $\left.394.75 \mathrm{~m}^{-2}\right)$, grains per spike $(42.5$ and 43.25), and 1000-grain weight (43.25 and $44.07 \mathrm{~g}$ ) during the first and second year of study, respectively. However, this treatment remained statistically at par with iodosulfuron-methyl sodium + adjuvant in the year 2013-14 and with all the herbicides mixed with an adjuvant and iodosulfuron-methyl sodium alone in year 2014-15 regarding spike bearing tillers. The increase in the number of spike bearing tillers of wheat crop by application of herbicides was attributed to reduction in weed infestation and competition with crop for growth factors. That was why crop plants produced a higher number of tillers per unit area under a weed-free environment. These results were in line with those of Tagour et al. (2011), who concluded that Traxos when applied at $500 \mathrm{~cm}^{3}$ tank-mixed with Arkopal N100 at 4 and 8\% followed by Topik at $140 \mathrm{~g}$ tank-mixed with

Table 4 - Effect of herbicides with and without an adjuvant on yield and yield attributes of Triticum aestivum

\begin{tabular}{|c|c|c|c|c|c|c|c|c|c|c|c|c|}
\hline \multirow[t]{2}{*}{ Herbicide } & \multirow{2}{*}{$\begin{array}{c}\text { Rate } \\
\left(\mathrm{g} \text { a.i. ha }{ }^{-1}\right)\end{array}$} & \multirow[t]{2}{*}{ Adjuvant } & \multicolumn{2}{|c|}{$\begin{array}{l}\text { Spike bearing tillers } \\
\left(\mathrm{m}^{-2}\right)\end{array}$} & \multicolumn{2}{|c|}{$\begin{array}{l}\text { Grains per spike } \\
\text { (No.) }\end{array}$} & \multicolumn{2}{|c|}{$\begin{array}{l}\text { 1000-grains weight } \\
\text { (g) }\end{array}$} & \multicolumn{2}{|c|}{$\begin{array}{l}\text { Grain yield } \\
\left(\mathrm{kg} \mathrm{ha}^{-1}\right)\end{array}$} & \multicolumn{2}{|c|}{$\begin{array}{l}\% \text { increase in grain } \\
\text { yield over control }\end{array}$} \\
\hline & & & $2014-15$ & 2013-14 & $2014-15$ & 2013-14 & $2014-15$ & 2013-14 & $2014-15$ & 2013-14 & $2014-15$ & $2013-14$ \\
\hline Un-weeded control & - & - & $291.50 \mathrm{c}$ & $280.75 \mathrm{e}$ & $30.25 \mathrm{~d}$ & $30.50 \mathrm{~d}$ & $35.25 \mathrm{e}$ & $39.47 \mathrm{c}$ & $3315.3 \mathrm{f}$ & $3139.8 \mathrm{e}$ & - & - \\
\hline $\begin{array}{l}\text { Fluroxypyr + tribenuron- } \\
\text { methyl + clopyralid }\end{array}$ & 244.5 & - & $325.50 \mathrm{bc}$ & $309.50 \mathrm{de}$ & $35.75 \mathrm{c}$ & $35.75 \mathrm{c}$ & $37.80 \mathrm{~d}$ & $42.45 \mathrm{ab}$ & 3662.0 ef & $3487.5 \mathrm{de}$ & 10.45 & 11.07 \\
\hline $\begin{array}{l}\text { Mesosulfuron-methyl }+ \\
\text { iodosulfuron-methyl sodium }\end{array}$ & 14.2 & - & $331.50 \mathrm{bc}$ & 314.5 cde & $36.75 \mathrm{bc}$ & $37.75 \mathrm{bc}$ & $38.40 \mathrm{~d}$ & $41.40 \mathrm{abc}$ & $3826.3 \mathrm{de}$ & 3717 cde & 15.41 & 18.38 \\
\hline Bromoxynil + MCPA & 444.6 & - & $340.50 \mathrm{bc}$ & $322.0 \mathrm{bcd}$ & $37.00 \mathrm{bc}$ & $39.75 \mathrm{ab}$ & $39.80 \mathrm{~cd}$ & $40.55 \mathrm{bc}$ & 3929 cde & $3824.5 \mathrm{~cd}$ & 18.52 & 21.80 \\
\hline Iodosulfuron-methyl sodium & 10 & - & $350.75 \mathrm{ab}$ & $329.5 \mathrm{bcd}$ & $38.75 \mathrm{ab}$ & $40.75 \mathrm{ab}$ & $40.92 \mathrm{bc}$ & $41.30 \mathrm{abc}$ & $4046.8 \mathrm{~cd}$ & $3913.8 \mathrm{~cd}$ & 22.06 & 24.65 \\
\hline $\begin{array}{l}\text { Fluroxypyr + tribenuron- } \\
\text { methyl +clopyralid }\end{array}$ & $183.3^{(1)}$ & $\begin{array}{l}\text { Alkyl ether sulfate } \mathrm{Na} \\
\text { salt @ } 400 \mathrm{~mL} \mathrm{ha}^{-1}\end{array}$ & $359.75 \mathrm{ab}$ & $338.75 \mathrm{bcd}$ & $39.25 \mathrm{abc}$ & $39.00 \mathrm{~b}$ & $41.95 \mathrm{abc}$ & $40.47 \mathrm{bc}$ & $4219.5 \mathrm{bc}$ & $4091.8 \mathrm{bc}$ & 27.27 & 30.29 \\
\hline $\begin{array}{l}\text { Mesosulfuron-methyl + } \\
\text { iodosulfuron-methyl sodium }\end{array}$ & $10.6^{(1)}$ & $\begin{array}{c}\text { Alkyl ether sulfate } \mathrm{Na} \\
\text { salt @ } 400 \mathrm{~mL} \mathrm{ha}^{-1}\end{array}$ & $354.00 \mathrm{ab}$ & $346.75 \mathrm{bc}$ & $41.00 \mathrm{ab}$ & $40.00 \mathrm{ab}$ & $42.02 \mathrm{ab}$ & $41.95 \mathrm{abc}$ & $4523.8 \mathrm{~b}$ & $4201.3 \mathrm{bc}$ & 36.45 & 33.80 \\
\hline Bromoxynil + MCPA & $333.4^{(1)}$ & $\begin{array}{l}\text { Alkyl ether sulfate Na } \\
\text { salt @ } 400 \mathrm{~mL} \mathrm{ha}^{-1}\end{array}$ & $394.75 \mathrm{a}$ & $382.50 \mathrm{a}$ & $42.50 \mathrm{a}$ & $42.50 \mathrm{a}$ & $44.07 \mathrm{a}$ & $43.25 \mathrm{a}$ & $5159.0 \mathrm{a}$ & $4902.3 \mathrm{a}$ & 55.61 & 56.13 \\
\hline Iodosulfuron-methyl sodium & $7.5^{(1)}$ & $\begin{array}{l}\text { Alkyl ether sulfate Na } \\
\text { salt @ } 400 \mathrm{~mL} \mathrm{ha}^{-1}\end{array}$ & $365.00 \mathrm{ab}$ & $351.50 \mathrm{ab}$ & $40.50 \mathrm{ab}$ & $40.75 \mathrm{ab}$ & $43.00 \mathrm{ab}$ & $42.25 \mathrm{ab}$ & $4891.0 \mathrm{a}$ & $4566.5 \mathrm{ab}$ & 47.52 & 45.43 \\
\hline HSD & & & 51.98 & 35.62 & 10.331 & 10.783 & 10.331 & 10.783 & 353.53 & 581.18 & - & - \\
\hline \multicolumn{13}{|c|}{ Contrasts } \\
\hline Weedy check vs all & & & $\begin{array}{l}291.5 \text { vs } \\
352.71 * *\end{array}$ & $\begin{array}{l}280.75 \text { vs } \\
336.87^{* *}\end{array}$ & $\begin{array}{l}30.25 \text { vs } \\
38.93 * *\end{array}$ & $\begin{array}{l}30.5 \mathrm{vs} \\
39.53^{* *}\end{array}$ & $\begin{array}{l}35.25 \text { vs } \\
40.99^{* *}\end{array}$ & $\begin{array}{l}39.4 \text { vs } \\
41.7 * *\end{array}$ & $\begin{array}{l}3315.25 \text { vs } \\
4282.18^{* *}\end{array}$ & $\begin{array}{l}3139.75 \mathrm{vs} \\
4088.06^{* *}\end{array}$ & - & - \\
\hline $\begin{array}{l}\text { Herbicides without adjuvant } \\
\text { vs herbicides with adjuvant }\end{array}$ & & & $\begin{array}{l}337.06 \mathrm{vs} \\
368.37^{* *}\end{array}$ & $\begin{array}{l}318.87 \text { vs } \\
354.87^{* *}\end{array}$ & $\begin{array}{l}37.06 \text { vs } \\
40.81^{* *}\end{array}$ & $\begin{array}{l}38.5 \mathrm{vs} \\
40.56^{*}\end{array}$ & $\begin{array}{l}39.23 \mathrm{vs} \\
42.76^{* *}\end{array}$ & $\begin{array}{l}41.42 \text { vs } \\
41.98^{\text {NS }}\end{array}$ & $\begin{array}{l}3866.06 \text { vs } \\
4698.31^{* *}\end{array}$ & $\begin{array}{l}3735.68 \text { vs } \\
4440.43^{* *}\end{array}$ & - & - \\
\hline
\end{tabular}

(1) Reduced rate $(75 \%$ of the recommended rate); Means sharing the same letter did not differ significantly at $p \leq 0.05$. 
an adjuvant at $4 \%$, Traxos at $75 \%$ reduced rate i.e. $375 \mathrm{~cm}^{3}$ tank-mixed with an adjuvant at $8 \%$, Topik at 140 and $105 \mathrm{~g}$ tank-mixed with an adjuvant at $8 \%$, Traxos at $375 \mathrm{~cm}^{3}$ and Topik at $126 \mathrm{~g}$ tank-mixed with an adjuvant at $4 \%$ treatments, increased herbicide efficacy against weeds and produced a higher number of spikes $\mathrm{m}^{-2}$.

All herbicide treatments showed better performance compared with the unweeded control regarding number of grains per spike and 1000-grain weight of wheat with tank mixed adjuvant compared to herbicides applied alone during both years of study. The increase in grains per spike of wheat as a result of herbicide application compared with the control treatment might be the consequence of better growth of wheat as a result of better weed growth. Our findings were in line with those of Hussain et al. (2013). They inferred that application of bromoxynil + MCPA and clodinafop-propargyl together increased the number of grains per spike by controlling weeds. Post-emergence application of carfentrazone + sulfosulfuron with a surfactant at $45 \mathrm{~g}$ a.i. ha ${ }^{-1}$ led to minimum density with a positive increase in the number of grains per spike of wheat and it was at par with 54 and $90 \mathrm{~g}_{\text {a.i. }} \mathrm{ha}^{-1}$ (Singh et al., 2013a). An increase in 1000-grain weight by herbicide application compared with the weedy check was attributed to weed control whose absence resulted in better growth of wheat crop especially during the grain filling period. These results were parallel to those of Ashrafi (2009), who evaluated the effect of bromoxynil + MCPA, isoproturon and triasulfuron on yield and yield components of wheat. He mentioned that herbicide application significantly increased the yield components of wheat when compared with the weedy check. According to Singh et al. (2013a), post-emergence application of carfentrazone + sulfosulfuron with a surfactant at $45 \mathrm{~g}$ a.i. $\mathrm{ha}^{-1}$ recorded minimum density with positive increase in yield components of wheat and it was at par with 54 and $90 \mathrm{~g}$ a.i. ha ${ }^{-1}$.

\section{Grain yield (kg ha-1)}

Grain yield is the principal and primary parameter for assessment of any weed control treatment applied in experimentation. Effect of herbicides without an adjuvant and with alkyl ether sulfate sodium salt on wheat grain yield is shown in Table 4 . The data show that all herbicide treatments except for fluroxypyr + tribenuron-methyl + clopyralid without an adjuvant significantly increased grain yield over the check during both years. Application of herbicides along with an adjuvant produced 4440.43 and $4698.31 \mathrm{~kg} \mathrm{ha}^{-1}$ grain yields of wheat during years 2013-14 and 2014-15, respectively, which was significantly higher than those recorded with herbicides alone as indicated by contrast comparison. Among all herbicide treatments, $75 \%$ rates of bromoxynil + MCPA and iodosulfuron-methyl sodium along with alkyl ether sulfate adjuvant gave significantly higher (4902.3 and $5159.0 \mathrm{~kg} \mathrm{ha}^{-1}$ and 4566.5 and $4891.0 \mathrm{~kg} \mathrm{ha}^{-1}$ ) grain yields during years 2013-14 and 2014-15, respectively.

An increase in grain yield from the plots sprayed with bromoxynil + MCPA and iodosulfuronmethyl sodium at their $25 \%$ reduced application rates along with alkyl ether sulfate Na salt at $400 \mathrm{~mL} \mathrm{ha}^{-1}$ was due to the increase in the number of spike-bearing tillers, number of grains per spike and 1000-grains weight. These results were in line with those of Chhokar et al. (2011), who reported that the optimum rate of ready mixture (RM) sulfosulfuron + carfentrazone at $45 \mathrm{~g}$ a.i. ha- ${ }^{-1}$ with $625-750 \mathrm{~mL} \mathrm{ha}^{-1}$ surfactant was higher than sulfosulfuron alone, as it gave better control of Rumex dentatus and therefore $7.6 \%$ higher wheat yield. Our findings were also in conformity with those of Singh et al. (2013a), who evaluated the bio-efficacy of carfentrazoneethyl + sulfosulfuron in wheat to control C. album, $R$. dentatus, Phalaris minor, Anagalis arvensis and Melilotus spp. The results revealed that post-emergence application of carfentrazone + sulfosulfuron with a surfactant at $45 \mathrm{~g}$ a.i. ha-1 recorded minimum density with positive increase in yield and yield components of wheat and it was at par with 54 and $90 \mathrm{~g}$ a.i. ha ${ }^{1}$, without any phytotoxicity on the crop. Our findings were also consistent with those of Javaid and Tanveer (2013), who concluded that the increase in wheat grain yield was higher with herbicides at reduced rates and with alkyl ether sulfate sodium salt when compared with herbicides at recommended rates without adjuvants.

Response of C. arvensis and C. album differs with herbicides applied either alone or with an adjuvant because different herbicides work based on their site-specific mode of action and tank mixing with an adjuvant. It was concluded that bromoxynil + MCPA at $333.4 \mathrm{~g}$ a.i. ha $\mathrm{h}^{-1}+$ alkyl ether sulfate $\mathrm{Na}$ salt at $400 \mathrm{~mL} \mathrm{ha}^{-1}$ and iodosulfuron-methyl sodium at $7.5 \mathrm{~g}$ a.i. ha-1 + alkyl 
ether sulfate $\mathrm{Na}$ salt at $400 \mathrm{~mL} \mathrm{ha}^{-1}$ were found to be the most effective for controlling C. arvensis and C. album population and resulted in higher grain yield (55.61-56.13 and 45.43-47.52\%) over the check and (34.33-37.09 and 20.78-25.46\%) over these herbicides applied alone. The rates of these herbicides, with the addition of an adjuvant, could be reduced by $25 \%$ than the currently recommended rate without an added adjuvant. A comparison of the cost shows that the most cost-effective treatment is bromoxynil + MCPA at $333.4 \mathrm{~g}$ a.i. ha ${ }^{-1}$ with the addition of an adjuvant (data not shown).

\section{ACKNOWLEDGMENTS}

We gratefully acknowledge the staff of Institute of Animal Sciences and Farm area of the University of Agriculture Faisalabad, Pakistan, for their technical support while we were conducting the experiments of this study.

\section{REFERENCES}

Abbas S.H. et al. Agro economic evaluation of weeding techniques in wheat under rain-fed conditions. Pak J Weed Sci Res. 2014;20(2):183-98.

Armin M, Asghripour M. Effect of plant density on wild oat competition with competitive and non-competitive wheat cultivars. Agric Sci China. 2011;10(10):1554-61.

Ashrafi Z. Study effects of planting methods and tank mixed herbicides on weeds controlling and wheat yield. J Agric Sci. 2009;1(1):101.

Bellinder R.R. et al. Effect of weed growth stage and adjuvant on the efficacy of fomesafen and bentazone. Weed Sci. 2003;51(6):1016-21.

Bryan G.Y. et al. Glyphosate translocation in common lambsquarters (Chenopodium album) and velvetleaf (Abutilon theophrasti) in response to ammonium sulfate. Weed Sci. 2003;51(2):151-6.

Chhokar R.S. et al. Optimizing the surfactant dose for sulfosulfuron and ready mix combination of sulfosulfuron and carfentrazone against weeds in wheat. Ind J Weed Sci. 2011;43(3):153-62.

Devendra R. et al. Influence of surfactants on efficacy of different herbicides in control of Cyperus rotundus and Oxalis latifola. Current Sci. 2004;86(8):8-86.

Donald W.W. Chlorsulfuron (glean) for control of shoot growth and root buds of Canada thistle. Farm Res. 2010;43(4):20-22.

Duman F. et al. Biological response of a non-target aquatic plant (Nasturtium officinale) to the herbicide, tribenuron-methyl. Weed Biol Mange. 2010;10(2):81-90.

Han Y., Tao B. Effect of adjuvants on characteristics and performance to weeds. Adv Biomed Eng. 2011;3:186-9.

Hess F.D., Foy C.L. Interaction of surfactants with plant cuticles. Weed Technol. 2000;14(4):807-13.

Hussain Z. et al. Evaluation of various herbicides and their combinations for weed control in wheat crop. Pak J Bot. 2013;45(1):55-9.

Javaid M.M. et al. Optimizing activity of herbicides at reduced rate on Emex spinosa Campd. with adjuvants. Planta Daninha. 2012;30(2):425-35.

Javaid M.M., Tanveer A. Optimization of application efficacy for post herbicides with adjuvants on three- corned jack (Emex australis Steinhell) in wheat. Weed Technol. 2013;27(3):437-44.

Kahramanoglu I, Uygur F.N. The effects of reduced doses and application timing of metribuzin on redroot pigweed (Amaranthus retroflexus L.) and wild mustard (Sinapis arvensis L.). Turk J Agric Fores. 2010;34(6):467-74.

Kirkwood R.C. Use and mode of action of adjuvants for herbicides: a review of some current work. Pestic Scien. 1993;38(2-3):93-102. 
Knezevic S.Z. et al. Adjuvants influenced saflufenacil efficacy on fall-emerging weeds. Weed Technol. 2009;23(3):340-5.

Malik M.A. et al. Weed diversity in wheat fields of Upper Indus Plains in Punjab, Pakistan. Pak J Weed Sci Res. 2012;18(3):413-21.

Pakistan Agricultural Research - PARC. Wheat cultivation. Urdu brochure, Council. Islamabad: 2013.

Pannacci E. et al. Effect of adjuvants on the rain fastness and performance of tribenuron-methyl on broad-leaved weeds. Weed Biol Mange. 2010;10(2):126-31.

Penner D. Activator adjuvants 1. Weed Technol. 2000;12(4):785-91.

Pisal R.R, Sagarka BK. Integrated weed management in wheat with new molecules. Ind J Weed Sci. 2013;45(1):25-8.

Santos B.M. Drip-applied metam potassium and herbicides as methyl bromide alternatives for Cyperus control in tomato. Crop Prot. 2009;28(1):68-71.

Singh R.K. et al. Bio-efficacy of carfentrazone-ethyl + sulfosulfuron in wheat. Ind J Weed Sci. 2013a;45(4):243-6.

Singh R.K. et al. Weed control efficiency of herbicides in irrigated wheat (Triticum aestivum). Ind Res J Ext Edu. 2013b;13(1):126-8.

Steel R.G.D. et al. Principles and procedures of statistics. A biometrical approach. $3^{\text {rd }}$.ed. New York: McGraw Hill Book, 1996. $672 \mathrm{p}$.

Tagour R.M.H. et al. Improving herbicides efficacy of topic and traxos on Wheat plants and associated weeds by adjuvants arkopal. Nature Sci. 2011;9(11):171-80.

Varshney J.G., Singh H.G. Effect of adjuvants on herbicide efficacy in controlling weeds in wheat. Weed Sci. 1990;38(3):229-36.

Wolf B. A comprehensive system of leaf analysis and its use for diagnosing crop nutrient status. Comm Soil Sci Plant Anal. 1982;13(12):1035-59. 